\title{
PENDETEKSIAN FRAUD DIAMOND THEORY \\ TERHADAP PROFITABILITAS DENGAN MANAJEMEN LABA JONES THEORY SEBAGAI VARIABEL MODERATOR
}

\author{
Niken Savitri Primasari \\ Fakultas Ekonomi dan Bisnis, Universitas Nahdlatul Ulama Surabaya
}

Email :niken@unusa.ac.id

\begin{abstract}
The investor attention to earnings, might determines management's actions to take vital interests in financial reporting to show a favorable situation. Earnings management is often considered a rational and fair action principally. This manipulation is more due to the urge to keep the company's shares in demand by investors who tend to see profitability over a period of time to invest their capital in the company's shares, because for investors, because the company's profit will describe the company's overall value. This led to an increase in fraudulent actions. This study aims to analyze and find empirical evidence about the effect of fraud fraud factor based on diamond fraud, namely Pressure, Opportunity, Rationalization and Capability on financial statement fraud, which is proxied by the independent variables, namely financial stability, external pressure, financial targets, industrial conditions, ineffectiveness of supervision, audit opinions and the ability of the audit team in the financial sector to the level of profitability as the dependent variable with earnings management as moderating. All variables tend to be said to be influential except for leverage.
\end{abstract}

Keywords: Diamond Fraud, Profitability, Profit Management

\section{Pendahuluan}

Besarnya perhatian investor terhadap laba akhirnya menentukan pula tindakan manajemen perusahaan untuk mengambil kepentingan vital dalam cara pelaporan laba dan pemanajemenan laba perusahaan tersebut. Terutama untuk menyembunyikan kerugian-kerugian perusahaan, laba diatur untuk menunjukkan situasi yang menguntungkan. Manajemen laba sering dianggap sebuah tindakan yang rasional dan adil secara prinsipal. Karena dilakukan manajemen dengan penggunaan dasar akrual untuk penyusunan laporan keuangan. Hal ini menyajikan bila manajemen laba merupakan variabel moderator dalam penyajian tingkat profitabilitas perusahaan. Perusahaan manufaktur merupakan jumlah perusahaan yang terbanyak di Bursa Efek Indonesia yang juga memiliki tingkat kompleksitas transaksi yang tinggi pada laporan keuangan, oleh karena itu pemilihan sampel penelitian yang dipilih adalah kelompok industri manufaktur dasar. 
Penelitian inimencoba untuk melihat factor-faktor yang dapat mendeteksi kecurangan laporan keuangan, dengan metode fraud diamond. Peneliti mengadopsi penelitian Annisya et al (2016) yang bertujuan untuk menganalisis dan menemukan bukti empiris mengenai pengaruh fraud risk factor menurut fraud diamond. Perbedaan penelitian ini dengan penelitian sebelumnya adalah pada keberpengaruhan Fraud terhadap tingkat profitabilitas perusahaan dengan manajemen laba sebagai variable moderator. Penelitian ini menggunakan tujuh variabel proksi independen yaitu stabilitas keuangan, tekanan eksternal, target keuangan, kondisi industri, efektifitas pengawasan, opini audit dan kemampuan tim audit di bidang keuangan. Variabel proksi tersebut mewakili variabel independen dalam fraud diamond yaitu tekanan, kesempatan, rasionalisasi, dan kemampuan terhadap tingkat profitabilitas perusahaan sebagai variabel dependen yang diproksikan dengan nilai Gross Profit Margin (GPM) dan Net Profit Margin (NPM). Mengingat tingkat profitabilitas perusahaan juga dipengaruhi oleh manajemen laba, maka manajemen laba diperlakukan sebagai variable moderating sebagai salah satu jenis variabel yang memiliki kemampuan dalam memperkuat atau bahkan memperlemah suatu hubungan secara langsung yang terjadi antara variabel independen dengan variabel dependen.

\section{Kerangka Teoritis dan Hipotesis}

1. Pengertian Fraud dan Fraud Diamond

Fraud diamond merupakan bentuk penyempurnaan dari fraud triangle, berupa faktor-faktor yang mempengaruhi seseorang melakukan kecurangan, dengan elemen capability. Sehingga, fraud diamond terdiri dari empat elemen penyebab terjadinya kecurangan. Adapun elemen-elemen dari fraud diamond theory yaitu tekanan (1) Tekanan (Pressure) adalah dorongan orang untuk melakukan fraud. Sebuah tekanan yang umum bagi perusahaan untuk memanipulasi laporan keuangannya adalah adanya penurunan dalam prospek keuangan perusahaan. (2) Peluang (Opportunity), adalah kondisi yang memberikan kesempatan bagi manajemen atau pegawai untuk menyalahsajikan laporan keuangan. Peluang dapat terjadi karena pengendalian internal yang lemah, pengawasan manajemen yang kurang baik atau melalui penggunaan posisi. Dalam SAS No. 99 menyebutkan bahwa peluang pada kecurangan laporan keuangan dapat terjadi pada tiga kategori. Kondisi tersebut adalah kondisi industri, ketidakefektifan pengawasan, dan struktur 
organisasional. (3)Rasionalisasi, merupakan bagian dari fraud triangle yang paling sulit diukur. Sikap atau karakter adalah apa yang menyebabkan satu atau lebih individu untuk secara rasional melakukan fraud. Dalam SAS No. 99 menyebutkan bahwa rasionalisasi pada perusahaan dapat diukur dengan pergantian auditor dan opini audit. (4) Kemampuan (Capability), menyebutkan bahwa posisi seseorang dalam organisasi dapat memberikan kemampuan dalam memanfaatkan kesempatan untuk melakukan penipuan. Adapun sifat-sifat yang dijelaskan Wolfe dan Hermanson terkait elemen kemampuan (capability) dalam tindakan pelaku kecurangan yaitu: Position/function, brains, confidencelego, coercion skills, effective lying, immunity to stress.

2.Profitabilitas

Profitabilitas dapat digunakan untuk mengukur efektivitas perusahaan didalam menghasilkan profit untuk setiap assets yang ditanam. Berdasarkan definisi tersebut dapat diketahui bahwa profitabilitas merupakan kemampuan perusahaan dalam memperoleh laba selama periode tertentu dengan modal atau aktiva yang dimiliki oleh perusahaan yang dapat menunjukkan keberhasilan perusahaan dalam menghasilkan keuntungan dan dapat digunakan oleh perusahaan dalam menilai tingkat pengembalian investasi dan penjualan berdasarkan dari jumlah laba yang diperoleh perusahaan. Mohammad Nur Fauzi (2015) menyatakan bahwa, "Tinggi rendahnya laba merupakan faktor penting perusahaan. Besar kecilnya laba perusahaan dapat diketahui melalui analisa laporan keuangan perusahaan dengan rasio profitabilitas."

Profitabilitas akan diproksikan dengan rasio Gross Profit Margin (GPM) dan Net Profit Margin (NPM). GPM menggambarkan laba kotor yang diperoleh dari aktifitas penjualan yang dilakukan oleh perusahaan. Rasio ini menggambarkan efisiensi yang dicapai oleh bagian produksi. NPM mengukur kemampuan perusahaan untuk menghasilkan laba bersih dari penjualan yang dilakukan perusahaan. Rasio ini mencerminkan efisiensi seluruh bagian, yaitu produksi, personalia, pemasaran, dan keuangan yang ada dalam perusahaan.

3.Manajemen Laba

Manajemen labadilakukan atas intervensi manajemen. Manajemen laba bukanlah sekedar menggeser periode pengakuan laba, tetapi mengarah pada upaya 
manajer untuk memberikan informasi yang salah kepada para stakeholder tentang kinerja perusahaan, sehingga stakeholder mengambil keputusan ekonomi sesuai dengan harapan manajer.

Adanya praktik manajemen laba membuat laporan keuangan dan informasi akuntansi lainnya disajikan tidak sesuai dengan kenyataan yang ada. "Manajemen laba" diyakini muncul sebagai konsekuensi dari upaya-upaya penyusun laporan keuangan untuk mengatur besaran nilai laba demi kepentingan perusahaan. Sebagai akibatnya, tindakan manajemen laba telah memunculkan beberapa kasus skandal pelaporan akuntansi secara luas melibatkan pelaporan keuangan yang terdeteksi adanya manipulasi.Discretionary accrualsakan digunakan sebagai proksi untuk manajemen laba yang dihitung dengan menggunakan Modified Jones Model.

\section{Hipotesis Penelitian}

$\mathrm{Ha}_{11}$ : Financial Stability berpengaruh terhadap kecurangan laporankeuangan yangsecara langsung akan berpengaruh pada tingkat profitabilitas sebagai akibat dari dampak manajemen laba yang diterapkan oleh perusahaan.

$\mathrm{Ha}_{21}$ : external pressure berpengaruh terhadap kecurangan laporan keuangan yang secara langsung akan berpengaruh pada tingkat profitabilitassebagai akibat dari dampak manajemen laba yang diterapkan oleh perusahaan

Ha31 : Financial target berpengaruh terhadap kecurangan laporan keuangan yang secara langsung akan berpengaruh pada tingkat profitabilitas sebagai akibat dari dampak manajemen laba yang diterapkan oleh perusahaan

Ha41: Nature of Industryberpengaruh terhadap kecurangan laporan keuangan Ineffective Monitoring berpengaruh terhadap kecurangan laporan keuanganyang secara langsung akan berpengaruh pada tingkat profitabilitassebagai akibat dari dampak manajemen laba yang diterapkan oleh Perusahaan.

Ha51:Ineffective monitoring berpengaruh terhadap kecurangan laporan keuanganyang secara langsung akan berpengaruh pada tingkat profitabilitassebagai akibat dari dampak manajemen laba yang diterapkan oleh Perusahaan. 
Ha61: Opini Audit berpengaruh terhadap kecurangan laporan keuangan yang secaralangsung akan berpengaruh pada tingkat profitabilitas sebagai akibat dari dampak manajemen laba yang diterapkan oleh perusahaan.

Ha71: Keahlian Tim Audit berpengaruh terhadap kecurangan laporan keuanganyang secara langsung akan berpengaruh pada tingkat profitabilitas sebagai akibat dari dampak manajemen laba yang diterapkan oleh perusahaan.

\section{Metode Penelitian}

1.Populasi dan Sampel Penelitian

Populasi dan sampel yang digunakan dalam penelitian ini adalah perusahaan yang terdaftar di Bursa Efek Indonesia (BEI). Populasi dalam penelitian ini adalah seluruh perusahaan yang terdaftar di Bursa Efek Indonesia pada tahun 2013 sampai dengan tahun 2017, dengan kriteria tertentu. Metode pengambilan sample yang akan digunakan adalah metode purposive sampling berdasarkan kriteria:(1) Perusahaan yang menyajikan laporan tahunannya dalam website perusahaan atau website BEI, www.idx.co.id selama periode 2013-2017. (2) Perusahaan yang tidak mengalami pailit dan delisting dari BEI dalam kurun waktu 2013-2017. (3) Laporan tahunan perusahaan memiliki data-data yang lengkap berkaitan dengan variabel penelitian dan laporan keuangan yang disajikan dalam bentuk mata uang rupiah.

2. Metode Analisis Data

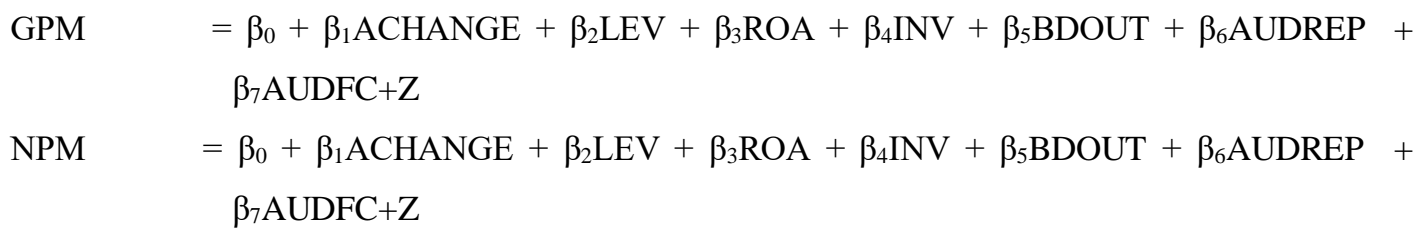

Keterangan :

$\begin{array}{ll}\text { GPM } & =\text { Return On Asset } \\ \text { NPM } & =\text { Kepemilikan Manajerial } \\ \text { ACHANGE } & =\text { Perubahan Total Asset } \\ \text { LEV } & =\text { Leverange yang diproksikan dengan Debt to Asset Ratio } \\ \text { ROA } & =\text { Return on Asset } \\ \text { INV } & =\text { Inventory }\end{array}$




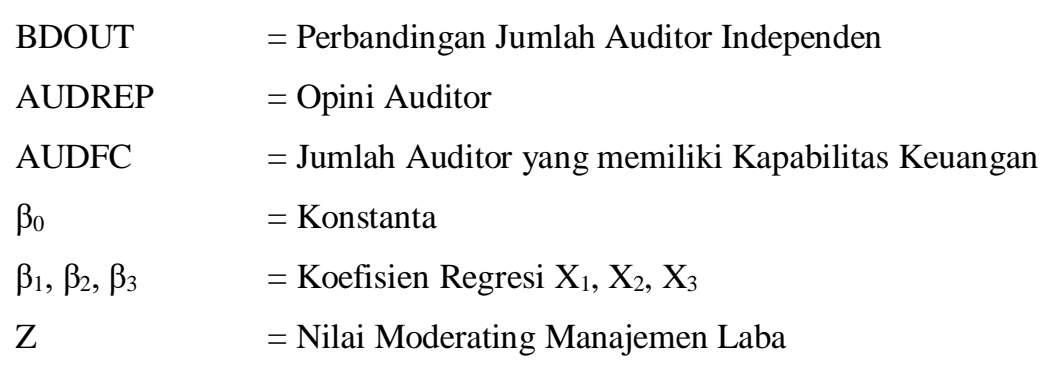

Model 1:

Untuk menghindari penolakkan input pada SPSS, maka khusus untuk variable AUDREP dan AUDCF, akan disatukan menjadi nilai AUDCR. Semua perusahaan akan mendapatkan nilai AUDCR maksimum, yakni 1, dan akan diberlakukan untuk seluruh pengujian pada penelitian ini. Sehingga model 1 dari tahap pengujian pertama dapat dituliskan sebagai berikut,

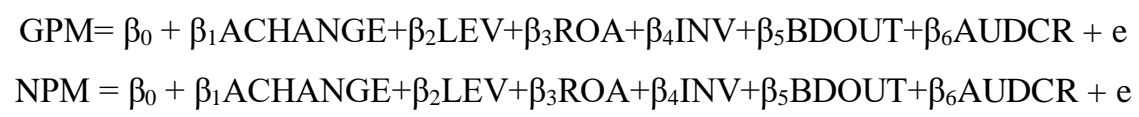

Model 2:

Memasukkan semua variable untuk mengetahui pengaruh pada tingkat profitabilitas sebagai akibat adanya variable moderasi tersebut, sehingga model pengujian untuk persamaan kedua akan menjadi

$\mathrm{GPM}=\beta_{0}+\beta_{1} \mathrm{ACHANGE}+\beta_{2} \mathrm{LEV}+\beta_{3} \mathrm{ROA}+\beta_{4} \mathrm{INV}+\beta_{5} \mathrm{BDOUT}+\beta_{6} \mathrm{AUDCR}+\beta_{7} \mathrm{ERMGM}+\mathrm{e}$

$\mathrm{NPM}=\beta_{0}+\beta_{1} \mathrm{ACHANGE}+\beta_{2} \mathrm{LEV}+\beta_{3} \mathrm{ROA}+\beta_{4} \mathrm{INV}+\beta_{5} \mathrm{BDOUT}+\beta_{6} \mathrm{AUDCR}+\beta_{7} \mathrm{ERMGM}+\mathrm{e}$

Model 3:

Moderated Regression Analysis (MRA) sebagai pendekatan analitik untuk integritas sampel dan memberikan dasar kriteria pengontrolansebagai cara melihat pengaruh variable moderator dalam persamaan regresi.

$\mathrm{GPM}=\beta_{0}+\beta_{1} \mathrm{ACHANGE}+\beta_{2} \mathrm{LEV}+\beta_{3} \mathrm{ROA}+\beta_{4} \mathrm{INV}+\beta_{5} \mathrm{BDOUT}+\beta_{6} \mathrm{AUDCR}+$

$\mathrm{B}_{7} \mathrm{ERMGM}+\beta_{8} \mathrm{Z}_{8}+\beta_{9} \mathrm{Z}_{9}+\beta_{10} \mathrm{Z}_{10}+\beta_{11} \mathrm{Z}_{11}+\beta_{12} \mathrm{Z}_{12}+\beta_{13} \mathrm{Z}_{13}+\mathrm{e}$

$\mathrm{NPM}=\beta_{0}+$

$\beta_{1} \mathrm{ACHANGE}+\beta_{2} \mathrm{LEV}+\beta_{3} \mathrm{ROA}+\beta_{4} \mathrm{INV}+\beta_{5} \mathrm{BDOUT}+\beta_{6} \mathrm{AUDCR}+\mathrm{B}_{7} \mathrm{ERMGM}+\beta_{8} \mathrm{Z}_{8}+\beta_{9} \mathrm{Z}_{9}+$

$\beta_{10} Z_{10}+\beta_{11} Z_{11}+\beta_{12} Z_{12}+\beta_{13} Z_{13}+e$

Model 4:

Melakukan uji residual sebagai pengolahan variable moderating

$\mathrm{GPM}=\beta_{0}+\beta_{1} \mathrm{ACHANGE}+\beta_{2} \mathrm{LEV}+\beta_{3} \mathrm{ROA}+\beta_{4} \mathrm{INV}+\beta_{5} \mathrm{BDOUT}+\beta_{6} \mathrm{AUDCR}+\mathrm{B}$ ERMGM +

$\beta_{8} \mathrm{ABSZ}_{8}+\beta_{9} \mathrm{ABSZ}_{9}+\beta_{10} \mathrm{ABSZ}_{10}+\beta_{11} \mathrm{ABSZ}_{11}+\beta_{12} \mathrm{ABSZ}_{12}+\beta_{13} \mathrm{ABSZ}_{13}+\mathrm{e}$

$\mathrm{NPM}=\beta_{0}+\beta_{1} \mathrm{ACHANGE}+\beta_{2} \mathrm{LEV}+\beta_{3} \mathrm{ROA}+\beta_{4} \mathrm{INV}+\beta_{5} \mathrm{BDOUT}+\beta_{6} \mathrm{AUDCR}+$

$\mathrm{B}_{7} \mathrm{ERMGM}+\beta_{8} \mathrm{ABSZ}_{8}+\beta_{9} \mathrm{ABSZ}_{9}+\beta_{10} \mathrm{ABSZ}_{10}+\beta_{11} \mathrm{ABSZ}_{11}+\beta_{12} \mathrm{ABSZ}_{12}+\beta_{13} \mathrm{ABSZ}_{13}+\mathrm{e}$

\section{Hasil Pembahasan}


Tabel 4.1

Uji Statistik Deskriptif

\begin{tabular}{lccccc}
\hline Variabel & $\mathbf{N}$ & Minimum & Maksimum & Rata-rata & Std. Deviasi \\
\hline ACHANGE & 155 & -1.00 & 1.65 & 0.79 & 0.28 \\
\hline LEV & 155 & 0.00 & 0.67 & 0.40 & 0.12 \\
\hline ROA & 155 & -0.54 & 1.89 & 0.04 & 0.17 \\
\hline INV & 155 & -0.04 & 9.58 & 0.51 & 0.93 \\
\hline BDOUT & 155 & 0.00 & 89.45 & 9.52 & 18.97 \\
\hline AUDREP & 155 & 1.00 & 1.00 & 1.00 & 0.00 \\
\hline AUDCF & 155 & 1.00 & 1.00 & 1.00 & 0.00 \\
\hline ERMGM & 155 & -10.05 & 0.11 & -4.32 & 3.54 \\
\hline GPM & 155 & -11.06 & 4.28 & 0.87 & 1.38 \\
\hline NPM & 155 & -3.28 & 12.06 & 0.13 & 1.38 \\
\hline
\end{tabular}

Sumber : Data Sekunder yang diolah SPSS, 2018

Kemungkinan awal terjadinya fraud dapat terlihat dari pembiasan informasi keuangan yang terlihat dari besarnya tingkat penyimpangan data. Adapun nilai selisih terbesar nilai penyimpangan terhadap nilai rata-rata, dapat dilihat pada table 4.2 sebagai berikut

Tabel 4.2

Selisih Nilai Penyimpangan terhadap Nilai Rata-Rata

\begin{tabular}{|c|c|c|c|c|c|}
\hline No & Variabel & Std. Deviasi & Rata-rata & Selisih & Rank \\
\hline 1 & BDOUT & 18,97 & 9,52 & 9,45 & 1 \\
\hline 2 & ERMGM & 3,54 & $-4,32$ & 7,86 & 2 \\
\hline 3 & NPM & 1,38 & 0,13 & 1,25 & 3 \\
\hline 4 & GPM & 1,38 & 0,87 & 0,51 & 4 \\
\hline 5 & INV & 0,93 & 0,51 & 0,42 & 5 \\
\hline 6 & ROA & 0,17 & 0,04 & 0,13 & 6 \\
\hline
\end{tabular}

Tabel 4.2 mengimplikasikan bila alur pemikiran fraud akan terlihat dari variable efektifitas monitoring (BDOUT). Manajemen laba (ERMGM) itu sendiri merupakan bentuk kebijakan internal perusahaan untuk menetapkan profitabilitas (NPM dan GPM). GPM tentunya juga dipengaruhi oleh kebijakan inventory perusahaan (INV). Seluruh pengambilan keputusan keuangan secara jangka panjang akan berpengaruh pada target financial perusahaan (ROA). Fraud akan muncul karena adanya motif perspektif peningkatan laba yang dilakukan para manajer untuk menaikkan nilaiperusahaan untuk dapat menarik minat investor. Sehingga dapat dikatakan bila diamond fraud mampu mengindikasi penyimpangan data dengan melakukan manajemen laba dengan perspektif opportunistik pada sampel.

\subsection{Uji Normalitas}

Tabel 4.3

Kolmogorov-Smirnov Test

\begin{tabular}{llrrrr}
\hline No & Indikator & Un.Res_1 & Un.Res_2 & Un.Res_3 & \multicolumn{1}{c}{ Un.Res_4 } \\
\hline $\mathbf{1}$ & N & 155 & 155 & 155 & 155 \\
\hline $\mathbf{2}$ & Mean & -1.98 & -9.95 & -1.21 & 7.58 \\
\hline
\end{tabular}




\begin{tabular}{llrrrr}
\hline $\mathbf{3}$ & Std. Deviasi & 1.36 & 1.31 & 1.30 & 1.30 \\
\hline $\mathbf{4}$ & Absolute Differences & .40 & .36 & .36 & .36 \\
\hline $\mathbf{5}$ & Positive Differences & .24 & .26 & .25 & .36 \\
\hline $\mathbf{6}$ & Negative Differences & -.40 & .36 & -.35 & -.25 \\
\hline $\mathbf{7}$ & Kolmogorov-Smirnov Z & .40 & .36 & .36 & .36 \\
\hline $\mathbf{8}$ & 2- Tailed Significant & .22 & .18 & .16 & .16 \\
\hline
\end{tabular}

Hasil pengujian One-Sample Kolmogorof-Smirnov menunjukkan bahwa semua

nilai residual dari metode penelitian terdistribusi secara normal.

\subsection{Uji Heteroskedastisitas}

Tabel 4.4

Uji Gletjer

\begin{tabular}{llrrrr}
\hline No & Variabel & $\begin{array}{c}\text { Signifikasi } \\
\text { model 1 }\end{array}$ & \multicolumn{1}{c}{ Signifikasi } \\
model 2 & $\begin{array}{c}\text { Signifikasi } \\
\text { model 3 }\end{array}$ & \multicolumn{1}{c}{$\begin{array}{c}\text { Signifikasi } \\
\text { model 4 }\end{array}$} \\
\hline $\mathbf{1}$ & Konstanta & .958 & .918 & .869 & .869 \\
\hline $\mathbf{2}$ & ACHANGE & .495 & .777 & .756 & .756 \\
\hline $\mathbf{3}$ & LEVERANGE & .361 & .124 & .114 & .114 \\
\hline $\mathbf{4}$ & ROA & .324 & .353 & .408 & .408 \\
\hline $\mathbf{5}$ & INVENTORY & .616 & .807 & .724 & .724 \\
\hline $\mathbf{6}$ & BDOUT & .000 & .000 & .000 & .000 \\
\hline $\mathbf{7}$ & ERMGM & - & .017 & .019 & .019 \\
\hline
\end{tabular}

Berdasarkan hasil pengujian gletjer diketahui bahwa nilai signifikasi

untuk seluruh variable berada di nilai yang lebih besar dari 0,05 kecuali untuk nilai BDOUT. Sekalipun BDOUT terindikasi terjadi masalah normalitas data, penelitian tetap akan dilanjutkan, ini dikarenakan central limit theorem.

\subsection{Uji Autokorelasi}

Tabel 4.5

Uji Durbin Watson

\begin{tabular}{lcccccccc}
\hline Model & N & K & dL & dU & 4-dU & 4-dL & DW & Keterangan \\
\hline I & 155 & 6 & 1.651 & 1.817 & 2.183 & 2.349 & 2.054 & Tidak terjadi Auto korelasi \\
\hline II & 155 & 7 & 1.637 & 1.832 & 2.168 & 2.363 & 2.089 & Tidak terjadi Auto korelasi \\
\hline III & 155 & 12 & 1.564 & 1.908 & 2.436 & 2.092 & 2.189 & Tidak terjadi Auto korelasi \\
\hline IV & 155 & 10 & 1.593 & 1.877 & 2.407 & 2.123 & 1.709 & Tidak terjadi Auto korelasi
\end{tabular}

Dari tabel tersebut dapat diketahui bila data yang terdapat pada penelitian

ini tidak terjadi autokorelasi, sehingga dapat dilakukan langkah pengujian berikutnya.

\subsection{Uji Multikolinearitas}

Tabel 4.6

Uji Multikolinearitas

\begin{tabular}{|c|c|c|c|}
\hline \multirow[t]{2}{*}{ Variabel } & \multicolumn{2}{|c|}{ Collinearity Statistic } & \multirow[t]{2}{*}{ Keterangan } \\
\hline & Tolerance & VIF & \\
\hline \multicolumn{4}{|c|}{ Model I (tanpa variable moderasi) } \\
\hline ACHANGE & 0.961 & 1.123 & Bebas Multikolinearitas \\
\hline LEV & 0.902 & 3.885 & Bebas Multikolinearitas \\
\hline ROA & 0.950 & 1.106 & Bebas Multikolinearitas \\
\hline INV & 0.952 & 1.374 & Bebas Multikolinearitas \\
\hline
\end{tabular}




\begin{tabular}{|c|c|c|c|}
\hline BDOUT & 0.939 & 1.335 & Bebas Multikolinearitas \\
\hline AUDCR & 0.068 & 4.795 & Bebas Multikolinearitas \\
\hline \multicolumn{4}{|c|}{ Model II (memasukkan variable moderasi) } \\
\hline ACHANGE & 0.886 & 1.129 & Bebas Multikolinearitas \\
\hline LEV & 0.720 & 3.930 & Bebas Multikolinearitas \\
\hline ROA & 0.880 & 1.137 & Bebas Multikolinearitas \\
\hline INV & 0.725 & 1.379 & Bebas Multikolinearitas \\
\hline BDOUT & 0.746 & 1.340 & Bebas Multikolinearitas \\
\hline AUDCR & 0.625 & 6.071 & Bebas Multikolinearitas \\
\hline ERMGM & 0.383 & 2.612 & Bebas Multikolinearitas \\
\hline
\end{tabular}

Model III (memasukkan variable moderasi dan interaksinya ke dalam persamaan regresi)

\begin{tabular}{lccl}
\hline ACHANGE & 0.222 & 4.514 & Bebas Multikolinearitas \\
\hline LEV & 0.129 & 7.427 & Bebas Multikolinearitas \\
\hline ROA & 0.572 & 1.748 & Bebas Multikolinearitas \\
\hline INV & 0.571 & 1.752 & Bebas Multikolinearitas \\
\hline BDOUT & 0.432 & 2.313 & Bebas Multikolinearitas \\
\hline AUDCR & 0.142 & 7.627 & Bebas Multikolinearitas \\
\hline ERMGM & 0.232 & 4.317 & Bebas Multikolinearitas \\
\hline Z1 & 0.202 & 4.511 & Bebas Multikolinearitas \\
\hline Z2 & 0.537 & 1.863 & Bebas Multikolinearitas \\
\hline Z3 & 0.323 & 3.093 & Bebas Multikolinearitas \\
\hline Z4 & 0.323 & 3.093 & Bebas Multikolinearitas \\
\hline Z5 & 0.379 & 2.639 & Bebas Multikolinearitas \\
\hline Z6 & 0.232 & 3.059 & Bebas Multikolinearitas \\
\hline Model IV (memasukkan variable moderasi dengan uji & residual) \\
\hline ACHANGE & 0.879 & 1.137 & Bebas Multikolinearitas \\
\hline LEV & 0.677 & 4.773 & Bebas Multikolinearitas \\
\hline ROA & 0.790 & 1.266 & Bebas Multikolinearitas \\
\hline INV & 0.573 & 1.746 & Bebas Multikolinearitas \\
\hline BDOUT & 0.569 & 1.757 & Bebas Multikolinearitas \\
\hline AUDCF & 0.544 & 1.391 & Bebas Multikolinearitas \\
\hline ERMGM & 0.263 & 3.806 & Bebas Multikolinearitas \\
\hline ABS(Z1) & 0.160 & 6.338 & Bebas Multikolinearitas \\
\hline ABS(Z3) & 0.832 & 2.161 & Bebas Multikolinearitas \\
\hline ABS(Z6) & 0.155 & 6.525 & Bebas Multikolinearitas \\
\hline
\end{tabular}

Dapat disimpulkan, bahwa semua variable tidak terjadi gejala multikolinearitas dalam model penelitian, baik untuk variable independen dan variable moderasi.

\subsection{Uji Signifikasi Simultan (Uji F)}

Tabel 4.7

Hasil Uji Signifikasi Simultan (uji F)

\begin{tabular}{ccccl}
\hline Model & df & F & Significant & Keterangan \\
\hline I $\left(\mathbf{Y}_{\mathbf{1}}\right)$ & 6 & 2.183 & 0.000190 & Berpengaruh secara simultan \\
\hline I $\left(\mathbf{Y}_{\mathbf{2}}\right)$ & 6 & 1.327 & 0.248000 & Tidak berpengaruh \\
\hline Model & df & \multicolumn{1}{c}{$\mathrm{F}$} & Significant & Keterangan \\
\hline II $\left(\mathbf{Y}_{\mathbf{1}}\right)$ & 7 & 10.771 & 0.000062 & Berpengaruh secara simultan \\
\hline II $\left(\mathbf{Y}_{2}\right)$ & 7 & 1.914 & 0.007100 & Berpengaruh secara simultan \\
\hline III $\left(\mathbf{Y}_{\mathbf{1}}\right)$ & 12 & 6.847 & 0.000011 & Berpengaruh secara simultan \\
\hline III $\left(\mathbf{Y}_{\mathbf{2}}\right)$ & 12 & 1.640 & 0.000869 & Berpengaruh secara simultan \\
\hline IV $\left(\mathbf{Y}_{\mathbf{1}}\right)$ & 10 & 10.874 & 0.000003 & Berpengaruh secara simultan \\
\hline IV $\left(\mathbf{Y}_{\mathbf{2}}\right)$ & 10 & 7.746 & 0.000046 & Berpengaruh secara simultan \\
\hline
\end{tabular}




\section{[ACCOUNTING GLOBAL JOURNAL] E ISSN 2623-1778}

Dari hasil uji simultan menunjukkan bila variable independen mampu mendeteksikecurangan pada laporan keuangan, dipengaruhi oleh manajemen laba.

\subsection{Uji Signifikasi Parsial (Uji t)}

\begin{tabular}{|c|c|c|c|c|}
\hline \multirow{2}{*}{ Variabel } & \multicolumn{3}{|c|}{$\begin{array}{l}\text { Tabel } 4.8 \\
\text { Hasil Uji Parsial } \\
\text { Nilai }\end{array}$} & \multirow{2}{*}{ Keterangan } \\
\hline & Beta & T hitung & Signifikasi & \\
\hline \multicolumn{5}{|l|}{ Model I } \\
\hline ACHANGE & -0.157 & -0.390 & 0.697 & Tidak Berpengaruh \\
\hline LEV & -0.447 & -0.456 & 0.649 & Tidak Berpengaruh \\
\hline ROA & -0.808 & -1.237 & 0.218 & Tidak Berpengaruh \\
\hline INV & 0.019 & 0.156 & 0.876 & Tidak Berpengaruh \\
\hline BDOUT & -0.014 & -2.249 & 0.026 & Berpengaruh \\
\hline AUDCR & 1.211 & 2.850 & 0.005 & Berpengaruh \\
\hline \multicolumn{5}{|l|}{ Model II } \\
\hline ACHANGE & -0.226 & -0.569 & 0.570 & Tidak berpengaruh \\
\hline LEV & -0.573 & -0.592 & 0.555 & Tidak berpengaruh \\
\hline ROA & -0.562 & -0.860 & 0.391 & Tidak berpengaruh \\
\hline INV & 0.036 & 0.299 & 0.765 & Tidak berpengaruh \\
\hline BDOUT & -0.013 & -2.141 & 0.034 & Berpengaruh \\
\hline AUDCR & 0.930 & 2.130 & 0.035 & Berpengaruh \\
\hline ERMGM & -0.072 & -2.283 & 0.024 & Berpengaruh \\
\hline \multicolumn{5}{|c|}{ Model III (memasukkan variable moderasi dan interaksinya ke dalam persamaan regresi } \\
\hline ACHANGE & 0.482 & 0.608 & 0.544 & Tidak berpengaruh \\
\hline LEV & -2.329 & -1.023 & 0.308 & Tidak berpengaruh \\
\hline ROA & 0.141 & 0.174 & 0.862 & Tidak berpengaruh \\
\hline INV & -0.043 & -0.317 & 0.752 & Tidak berpengaruh \\
\hline BDOUT & -0.021 & -2.630 & 0.009 & Berpengaruh \\
\hline AUDCR & 1.719 & 1.885 & 0.061 & Tidak berpengaruh \\
\hline ERMGM & 0.069 & 0.525 & 0.600 & Tidak berpengaruh \\
\hline $\mathrm{Z1}$ & -0.248 & -0.798 & 0.600 & Tidak berpengaruh \\
\hline $\mathrm{Z} 2$ & 0.305 & 1.315 & 0.426 & Tidak berpengaruh \\
\hline $\mathrm{Z3}$ & -0.030 & -0.664 & 0.190 & Tidak berpengaruh \\
\hline $\mathrm{Z} 4$ & -0.002 & -1.294 & 0.508 & Tidak berpengaruh \\
\hline $\mathrm{Z5}$ & -0.002 & 0.443 & 0.198 & Tidak berpengaruh \\
\hline Z6 & 0.064 & 0.501 & 0.617 & Tidak berpengaruh \\
\hline \multicolumn{5}{|c|}{ Model IV (memasukkan variable moderasi dan interaksi residual ke persamaan regresi) } \\
\hline ACHANGE & -0.390 & -2.257 & 0.026 & Berpengaruh \\
\hline LEV & 0.782 & 1.811 & 0.072 & Tidak berpengaruh \\
\hline ROA & -1.137 & -3.813 & 0.000 & Berpengaruh \\
\hline INV & 0.139 & 2.375 & 0.019 & Berpengaruh \\
\hline BDOUT & 0.011 & 3.765 & 0.000 & Berpengaruh \\
\hline AUDCR & 0.828 & -0.852 & 0.000 & Berpengaruh \\
\hline ERMGM & -0.000 & -0.020 & 0.984 & Tidak berpengaruh \\
\hline ABSZ1 & -0.248 & -0.899 & 0.370 & Tidak berpengaruh \\
\hline ABSZ3 & 0.584 & 1.497 & 0.137 & Tidak berpengaruh \\
\hline ABSZ6 & -1.389 & -4.760 & 0.000 & Berpengaruh \\
\hline
\end{tabular}

\subsection{Uji Koefisien Determinasi}

Tabel 4.9

Uji Determinasi $Y_{1}$ 


\begin{tabular}{|c|c|c|c|c|c|}
\hline No & Nilai & model 1 & model 2 & model 3 & model 4 \\
\hline \multicolumn{6}{|c|}{ Variabel Y 1 (GPM) } \\
\hline 1 & $\mathrm{R}$ & 0.561 & 0.581 & 0.604 & 0.937 \\
\hline 2 & R square & 0.314 & 0.337 & 0.365 & 0.879 \\
\hline 3 & Adjusted R square & 0.287 & 0.306 & 0.312 & 0.870 \\
\hline 4 & Error Estimate & 1.375 & 1.356 & 1.350 & 0.586 \\
\hline \multicolumn{6}{|c|}{ Variabel Y Y $_{2}$ (NM) } \\
\hline 1 & $\mathrm{R}$ & 0.225 & 0.288 & 0.348 & 0.912 \\
\hline 2 & $\mathrm{R}$ square & 0.051 & 0.083 & 0.121 & 0.832 \\
\hline 3 & Adjusted R square & 0.013 & 0.040 & 0.047 & 0.820 \\
\hline 4 & Error Estimate & 1.375 & 1.356 & 1.350 & 0.586 \\
\hline
\end{tabular}

Hasil uji Koefisien determinasi $\left(\mathrm{R}^{2}\right)$ menunjukkan hasil pengujian residu moderasi dalam persamaan regresi variable independen memberikan hasil $87 \%$ untuk GPM dan 82\% untuk NPM dapat dideteksi oleh Achange, Lev, Inv, ROA, BDOUT, AUDCR yang termoderasi oleh manajemen laba.

\section{Kesimpulan}

1. Hipotesis pertama, "Financial Stability", berpengaruh signifikan positif terhadap NPM dan sebaliknya berpengaruh signifikan negative terhadap GPM.

2. Hipotesis kedua, "External Pressure", tidak berpengaruh terhadap kecurangan laporan keuangan, menyatakan bahwa pihak manajemen lebih berusaha meningkatkan kinerjanya agar dapat menghasilkan keuntungan yang baik untuk memenuhi kewajibannya.

3. Hipotesis ketiga, "Financial Target" berpengaruh terhadap kecurangan laporan keuangan.

4. Hipotesis keempat, "Nature of Industry" berpengaruh terhadap kecurangan laporan keuangan. Menandakan bila persediaan mempunyai pengaruh yang besar terhadap laporan keuangan dipengaruhi oleh manajemen laba sebagai bentuk kebijakan internal perusahaan.

5. Hipotesis kelima, menyimpulkan bahwa masuknya dewan komisaris yang berasal dari luar perusahaan meningkatkan efektivitas dewan tersebut dalam mengawasi manajemen untuk mencegah kecurangan laporan keuangan.

6. Hipotesis keenam, opini audit berpengaruh terhadap kecurangan laporan keuangan. Opini tersebut merupakan bentuk tolerir dari auditor atas manajemen laba. Selain itu, opini audit sangat susah untuk diobservasi sebagai salah satu proksi dari rasionalisasi dengan data publik seperti laporan keuangan. 
7. Hipotesis ketujuh, kapabilitas, mengacu pada Profesionalisme audit dan kompetensi auditor internal berpengaruh secara signifikan dalam pendeteksian kecurangan penyalahgunaan pelaporan keuangan terutama kebijakan profitabilitas usaha.

\section{Daftar Pustaka}

ACFE, 2012. Report to The Nations on Occupational Fraud and Abuse - 2012 Global Fraud Study. (www.acfe.com/uploadedFiles/ACFE_Website/2012-report-tonations.pdf.,diakses tanggal 12 Maret 2016 pk 06.44 WIB)

Annisya, Mafiana. 2016. Pendeteksian Fraudulent Financial Statement dengan Analisis Fraud Diamond (Studi Empiris Perusahaan Jasa Sektor Properti dan Real Estate yang terdaftar di Bursa Efek Indonesia tahun 2010 - 2014). Skripsi. Fakultas Ekonomika dan Bisnis Universitas Lampung

Ardiyani \& Utaminingsih. 2015. Analisis Determinan Financial Statement MelaluiPendekatan Fraud Triangel. Accounting Analysis Journal. Vol 4 No 1. Hal. 110.

Arifulsyah, Hamdani. 2016. "Pengaruh Proporsi Kepemilikan Publik Terhadap Kinerja Keuangan Perusahaan, Dengan CSR Disclosure Sebagai Variabel Moderating”. Jurnal Akuntansi Keuangan dan Bisnis Vol. 9. Jurnal Politeknik Caltex Riau.

Association of Certified Fraud Examiners (ACFE). 2014. Report to Nation. Diaksesdari http://www.acfe.com/rttn/docs/2014-report-to-nations.pdf

Brigham, E.F., Ehrhardt, M.C. (2005), Financial Management Theory And Practice, Eleventh Edition, South Western Cengage Learning, Ohio.

Brochet, Franchois dan Zhan Gildao. 2004. "Managerial Entrachment and Earnings Smoothing”. Working Paper.

Fimanaya \& Syafruddin. 2014. Analisis Faktor - Faktor yang MempengaruhiKecurangan laporan Keuangan (Studi Empiris pada Perusahaan NonKeuangan yang Terdaftar di Bursa Efek Indonesia Tahun 2008 2011).Diponegoro Journal of Accounting, Vol. 03, No. 03, Hal. 1 -11.

Hartono, J., and Abdillah, W. 2014. Konsep and Aplikasi PLS (Partial Least Square) untuk Penelitian Empiris. Edisi pertama. Yogyakarta: BPFE.

Hapsari, Asri Dita. 2014. Pendeteksian Tingkat Fraud melalui Faktor Risiko, Tekanan, dan Peluang (Studi Kasus pada Perusahaan Perbankan periode 2010 - 2012). Naskah Publikasi Ilmiah. Universitas Muhammadiyah Surakarta

Kusumawardhani, Prisca. 2015. Deteksi Financial Statement Fraud dengan Analisis Fraud Triangle pada Perusahaan Perbankan yang Terdaftar di BEI. Naskah Publikasi Ilmiah. Fakultas Ekonomi Universitas Negeri Surabaya. 
Pardosi, Rica Widya. 2014. Analisis Fraud Diamond dalam Mendeteksi Kecurangan Laporan Keuangan pada Perusahaan Manufaktur di Indonesia dengan menggunakan Fraud Score Model (Tahun 2010 - 2013). Naskah Publikasi Ilmiah. Fakultas Ekonomi dan Bisnis, Universitas Lampung

Sihombing, Kennedy Samuel. 2014. Analisis Fraud Diamond dalam MendeteksiFinancial Statement Fraud : Studi Empiris Pada Perusahaan Manufakturyang Terdaftar di Bursa Efek Indonesia (BEI). Journal of Accounting FakultasEkonomi dan Bisnis, Universitas Diponegoro. Semarang. 